\title{
Regulation of Food Quality Development and Supervision in Denpasar City Putri Febyana Br Surbakti
}

\author{
Faculty of Law, Universitas Udayana
}

email: putri_febyana2202@yahoo.com

\begin{abstract}
Guidance and supervision of food quality needs to be carried out in each region because of it given the high victims of food poisoning in Indonesia. The absence of regulations governing food hygiene and safety and the lack of public awareness are the reasons for the high incidence of food poisoning. Therefore it requires a firm attitude from the central and regional governments and socialization for the community regarding the importance of food hygiene and safety. This research aims to analyze the regulation of supervision and supervision of food quality in Denpasar City and the form of supervision and coordination between related agencies in sanitation hygiene and food safety supervision in Denpasar City. This research is normative legal research. This research can be summarized as follows: First, there is no explicit arrangement regarding the development and supervision of food quality in Denpasar City, but implicitly contained in the Regional Regulations of Denpasar City Number 7 of 2008 concerning the Organization and Work Procedures of Denpasar City and the Regulation of Mayor of Denpasar Number 33 of 2008 concerning the Description of Job Duties in the Denpasar Municipal Service Organization; and Twice, and Twice, The Government of Denpasar City through the Health Office in collaboration with BBPOM routinely conducts checks and supervisions of sanitation and security of processed food which is marketed in various regions in Denpasar City.
\end{abstract}

Keywords : Guidance and Supervision; Food Quality; Regulation; Hygiene Sanitation; Food Security.

\section{INTRODUCTION}

The definition of food is contained in Law Number 18 of 2012 concerning Food. Food includes food and beverages to be a basic human need. Therefore, the need for food is increasing along with the growth of the population of a country. As a basic requirement, trade in foodstuffs and processed food products is found in every corner of Indonesia. Increasing food needs creates an increase in food sales. In addition to food sales, there are also sales of processed foods and beverages, even fast food processed, which is currently in demand by most Indonesians because it is considered practical and efficient. However, problems arise because processed food traders often do not pay attention to environmental and safety hygiene in food and beverage processing. This happened because regulations related to hygiene and safety of food quality were not effective, lack of supervision of traders, lack of public awareness of food quality, and lack of socialization of food hygiene and safety. As a result, there have been many cases of food poisoning. 
Based on data from the National Poisoning Information Center (SIKerNas), from January to March 2017, there were 23 incidents of food poisoning which were dominated by food poisoning as many as 19 incidents in which there were 17 incidents of food poisoning and 2 incidents of beverage poisoning. Then from April to June 2017, there were 31 incidents of food poisoning which were again dominated by food poisoning as many as 27 incidents in which there were 24 incidents of food poisoning described as follows: 1 incident due to consumption of processed food in packaging there were 4 victims; 4 incidents due to consumption of processed street food snacks (PKL) were 102 victims; 10 incidents due to processed food catering services have 666 victims; 9 incidents due to processed household food have 493 victims. And 3 incidents due to processed drinks there were 96 victims. Continued in July to September 2017 there were 39 incidents which were dominated by 30 food incidents in which there were 27 incidents of food poisoning described as follows: 9 incidents of food poisoning in food services there were 422 victims; 8 incidents of household food poisoning have 249 victims; 6 incidents of PKL processed food poisoning have 88 victims; 2 incidents of food poisoning in the pack have 22 victims; 1 incident of food poisoning which is unknown, there are 7 victims. And 3 incidents of drink poisoning have 16 victims ${ }^{1}$.

Food quality must be considered by every food and beverage business actor. ${ }^{2}$ Food quality is defined as the value determined on the basis of the safety criteria and nutritional content of food as referred to in Article 1 number 36 of Act Number 18 of 2012 concerning Food. Food quality consists of several aspects, namely nutritional aspects, business aspects and health aspects ${ }^{3}$. With the existence of food quality, it is hoped that producers or food entrepreneurs will pay more attention to the cleanliness of sanitation and the safety of processed food and beverages produced and sold. The community as consumers must also be aware of the importance of consuming processed food that is clean and safe so that it does not interfere with public health. The government has the most important role in creating regulations, fostering and supervising food hygiene and security to avoid outbreaks of malnutrition and food poisoning as recently happened, namely malnutrition in the Asmat Regency of Papua to death.

In Denpasar City there were several cases of food poisoning, namely in 2012, there were cases of food poisoning so that twenty-one people had to be hospitalized ${ }^{4}$. Then in 2014, there were food poisoning cases so that twenty-two people had to be hospitalized

${ }^{1}$ BPOM. (2018, 30 Januari). Berita Keracunan Bulan Juli - September 2017. Sentra Informasi Keracunan Nasional. Retrieved from http://ik.pom.go.id/v2016/berita-keracunan/berita-keracunan-bulab-juli-september-2017

${ }^{2}$ Hasan, K. N. S. (2014). Kepastian Hukum Sertifikasi dan Labelisasi Halal Produk Pangan. Dinamika Hukum, Universitas Jenderal Soedirman, 14(2), p. 232.

${ }^{3}$ Mamuaja, C. F. (2016). Pengawasan Mutu dan Keamanan Pangan. Manado: Unsrat Press, p. 7.

${ }^{4}$ Hasanudin, M. (2012). Puluhan Warga Denpasar Keracunan Nasi Bungkus. Kompas.com. Retrieved from https://nasional.kompas.com/read/2012/07/16/04384953/puluhan.warga.denpasar.keracunan.nasi.bungkus 
intensively due to the use of food preservatives ${ }^{5}$. In the same year, a seven-year-old child died from food poisoning purchased at a traveling snack dealer ${ }^{6}$. The case of food poisoning that causes casualties results in public anxiety about the amount of processed foods and drinks that are not safe. Therefore, more attention is needed from the Denpasar City Government to overcome the anxiety that arises in the community so as not to cause harm to businesses and the public as consumers. The government is required to conduct supervision which can prevent the dangers of processed foods and beverages that are unsafe to the community.

Based on this background, the authors found two problems that will be discussed further in this study, namely, first Is there a regulation related to the development and supervision of food quality in Denpasar City? And how is the supervision of sanitation hygiene and food security in the city of Denpasar?

The purpose of writing this scientific research is to analyze the arrangement of supervision and supervision of food quality in the city of Denpasar and the form of supervision and coordination between related agencies in the supervision of hygiene sanitation and food security in the city of Denpasar.

\section{METHOD}

This research is a type of normative legal research which is based on primary data sources in the form of laws, Minister of Health Decrees, Denpasar City Regional Regulations, Mayor Regulations, and secondary data sources in the form of journals and news from the official web.

\section{ANALYSIS AND DISCUSSION}

\section{A. Regulation of Food Quality Development and Supervision in Denpasar City}

Regulation becomes the authority regional government to regulate all matters that are the authority of the region. Regulations issued by local governments are often orders from higher regulations. As in the Decree of the Minister of Health No. 942/Menkes/SK/VII/2003 concerning Guidelines for Sanitation Food Snack Food Requirements, Article 19 requires district or city governments to further regulate food quality supervision and supervision. Guidance and supervision of food quality in the district/city are considered important to avoid extraordinary disasters such as malnutrition and food poisoning. In this case, the Denpasar City Government has not explicitly regulated the development and supervision of food quality so that a legal

${ }^{5}$ Sss. (2014). 22 Warga Denpasar Keracunan Ikan. detikNews. Retrieved from https://news.detik.com/ berita/191147/22-warga-denpasar-keracunan-ikan

${ }^{6}$ Surya, I. M. (2014). Bocah Tujuh Tahun Tewas Keracunan. Antara Bali. Retrieved from https://bali.antaranews. com/berita/60031/bocah-tujuh-tahun-tewas-keracunan 
vacuum occurs. However, in carrying out their duties and authority, the Denpasar City Government through the relevant agencies conducts food quality supervision based on job duties as implicitly regulated in the Regional Regulation of Denpasar City Number 7 of 2008 concerning the Organization and Work Procedures of the Regional Office of Denpasar City jo. Denpasar Mayor's Regulation Number 33 of 2008 concerning Job Position Descriptions at the Regional Office of the City of Denpasar.

In Article 6 of the Regional Regulation of Denpasar City Number 7 of 2008 concerning Organizations and Work Procedures for Regional Offices of the City of Denpasar that regulate the organizational structure. The offices whose job duties are related to the development and supervision of food quality, namely:

1. The Organizational Structure of the Health Office which is divided into several fields and sections, namely:

a) The Public Health Development Sector which covers the health promotion section and community participation and nutrition section

b) The Environmental Sanitation Development Division includes the restructuring section of public places (TTU), the food and beverage sanitation section and the neighborhood health and water quality restructuring section

2. The Organizational Structure of the Livestock, Fisheries and Marine Services Office which consists of fields and sections, namely: Health Sector Veterinary Society which includes supervision and guidance section of slaughterhouses, food and non-food quality supervision section, and traffic control section for food and non-food animal products.

3. Organizational Structure of the Office of Industry and Trade which consists of fields and sections, namely:

a) Field of Bina Sarana which covers the guidance section of industrial facilities and supervision section;

b) Field of Cooperation and Protection which includes the consumer protection section.

4. The Duties of the Service Organization Position as described above are further regulated in the Regulation of the Mayor of Denpasar Number 33 of 2008 concerning Job Position Descriptions at the Regional Service Organizations of the City of Denpasar, which are described as follows: Health Service

a. Field of Community Health Development (Article 30)

Section of Health Promotion and Community Participation (PSM) on duty

(1) preparing materials for the development of potential community participation

(2) in the health sector (Article 32 paragraph (1) letter q). 
The Nutrition Section is in charge of conducting Food and Nutrition Awareness System activities

(1) (SPKG) in order to anticipate the emergence of food and nutrition problems (Article (2) 32 paragraph (3) letter h).

b. Field of Environmental Health Development (Article 36)

(1) Public Health Restructuring Section (TTU) has the duty to carry out technical guidance and guidance, supervision and inspection of industrial places and public (Article 38 paragraph (1) letter g).

(2) Food and Beverage Restructuring Section has the duty to provide counseling, guidance, and supervision of restaurants and restaurants, catering services, home industry food (P-IRT), school canteens, snack food centers and other food processing places (Article 38 paragraph (2) letter $\mathrm{g}$ ).

(3) The Settlement Environment and Water Quality Section is tasked with planning and implementing health management guidance on the impact of pollution (Article 38 paragraph (3) letter k); carry out regulation, standardization and supervision of water quality (Article 38 paragraph (3) letter q); carry out counseling and improvement of water quality (Article 38 paragraph (3) letter r); carry out the provision and development of water quality facilities and infrastructure (Article 38 paragraph (3) letter t). Water is a sanitation facility to clean food so that clean and healthy water can improve food quality.

5. Department of Animal Husbandry, Fisheries and Marine Health of Veterinary Communities (Article 180)

1. Section of Supervision and Development of Slaughterhouses is tasked with establishing technical standards, guidance, monitoring and supervision of slaughterhouses (Article 182 paragraph (1) letter f); carry out guidance and supervision of animal shelters (Article 182 paragraph (1) letter g); carry out guidance and supervision of meat processing sites (Article 182 paragraph (1) letter $\mathrm{h}$ ).

2. The Food Quality and Non-Food Supervision Section is tasked with carrying out monitoring and quality control of food and non-food animal products and their distribution (Article 182 paragraph (2) letter f); carry out certification of food and non-food animal products (Article 182 paragraph (2) letter $\mathrm{g}$ ).

3. The Food and Non-Food Traffic Product Control Section has the duty to carry out monitoring and supervision of animal product traffic (Article 182 paragraph (3) letter g). 
6. Office of Industry and Trade

a. Field of Bina Sarana (Article 228)

1. The Industrial Development Section has the task of providing guidance and guidance on the use of raw/auxiliary materials in the field of industrial business (Article 230 paragraph (1) letter $\mathrm{h}$ ), preparing technical guidance materials for improving industrial production quality; preparing technical implementation instructions in improving the quality of industrial production (Article 230 paragraph (1) letters $m$ and $n$ ), providing technical guidance on production, product diversification and quality of chemical industry production, forest products, various industrial designs, metal product design, electronics and small industries household craft (Article 230 paragraph (1) letter o).

2. The Supervision Section is tasked with carrying out supervision and improvement of the quality of production, through fostering and implementing participatory management (Article 230 paragraph (3) letter f), coordinating with relevant agencies related to industrial waste processing technology (Article 230 paragraph (3) letter h ), implementing production quality standards through ISO coaching (Article 230 paragraph (3) letter i), preparing materials and carrying out technical guidance on the prevention or prevention of industrial waste, clean technology, machinery and environmentally friendly equipment, facilities and application of ISO 14000, application of eco-labeling, SNI (Article 230 paragraph (3) letter j).

b. Field of Cooperation and Protection (Article 232)

The Consumer Protection Section has the duty to provide guidance to consumers and producers regarding the rights and obligations of consumers and producers, actions/agreements that violate the rules for business actors and business actors' responsibilities (Article 233 paragraph (2) letter h), carry out guidance to producers to improve the quality of goods and or services that guarantee the continuity of the business of producing goods or services, health, comfort, security and consumer safety (Article 233 paragraph (2) letter k).

The Denpasar City Government has not implemented the provisions of Article 19 of the Decree of the Minister of Health Number 942/Menkes/SK/VII/2003 concerning Guidelines for the Requirements for Sanitation of Snack Food because of the lack of cases of food poisoning in Denpasar. However, preventive and anticipatory actions are the best for the benefit of the community given the many cases of food poisoning in regencies in Bali. Of course the duty from the health department; livestock, fisheries and marine services; and the industrial and trade services related to fostering and supervising food quality. However, the task of the Denpasar city government in 
fostering and supervising food quality should be regulated in a regulation so that the implementation of food quality supervision and supervision can run more effectively.

\section{B. Supervision of Sanitation and Food Safety Hygiene in Denpasar City}

Hygiene and sanitation in the processing of food and beverages are needed to avoid the transmission of disease through food or illness which is often experienced by the people of Indonesia due to lack of personal hygiene and environmental sanitation in the processing and serving of food and beverages ${ }^{7}$. The task of supervision over food security is carried out by the Deputy of Food Safety and Hazardous Material Supervision based on the Head of BPOM Decree Number 02001/SK/KBPOM of 2001 concerning the Organization of Work Procedures for the Drug and Food Supervisory Agency. Based on the provisions of Article 2 paragraph (1) of the Government Regulation of the Republic of Indonesia Number 28 of 2004 concerning Food Safety, Quality and Nutrition, the circulation of food must meet sanitation requirements. Then in paragraph (2) the sanitation requirements referred to are facilities and/or infrastructure; organizing activities; and individuals. According to Widyawati, hygiene or cleanliness is a human or individual effort to prevent the occurrence of disease in the environment where the person is located. ${ }^{8}$ In addition to the term hygiene, there is also the term sanitation which, according to Prabu, is a prevention effort that focuses on ensuring that food is not dangerous, starting from the production of food and beverages to being ready for consumption by consumers. ${ }^{9}$ In the process of processing food, a standard is needed, both sanitation standards and safety standards. In processing food, food producers must pay attention to the Sanitation Operational Procedure (SSOP) to avoid contamination of food and beverages ${ }^{10}$. There are several sanitation requirements,

1. Water security

Clean water is a means of cleaning food from pollution, but dirty water will only add a lot of pollution to food. Therefore, it is necessary to monitor water hygiene regularly.

2. Cleanliness of food processing equipment

Equipment and work clothes that are used to process food can be a source of pollution, therefore equipment to clothes used for work must be kept clean by routine cleaning after use.

\footnotetext{
${ }^{7}$ Islamy, G. P., Sumarmi, S., \& Farapti. (2018). Analisis Higiene Sanitasi dan Keamanan Makanan Jajanan di Pasar Besar Kota Malang. Amerta Nutrition, Universitas Airlangga, 2(1), pp. 29 - 36.

${ }^{8}$ Rahmadhani, D., \& Sumarmi, S. (2017). Gambaran Penerapan Prinsip Higiene Sanitasi Makanan di PT Aerofood Indonesia, Tangerang, Banten. Amerta Nutrition, Universitas Airlangga, 1(4), 291 - 299.

${ }^{9}$ /bid.

${ }^{10}$ Pudjirahaju, A. (2018). Bahan Ajar Gizi: Pengawasan Mutu Pangan. Jakarta: Kementerian Kesehatan Republik Indonesia, p. 73.
} 
3. Avoid cross contamination Cross

contamination occurs because clean food mixes with dirty food so that food is polluted.

4. Cleanliness of facilities

Hand washing facilities, sanitation and toilets are sources of contamination, so that they are cleaned as much as possible so as not to pollute foodstuffs.

5. Avoiding the ingredients that cause pollution

The substances that cause pollution are industrial chemicals whose use must be in accordance with established operational standards so as not to pollute foodstuffs.

6. Labeling, storage and use of toxic

chemicals Toxic chemicals must be labeled to avoid misuse. Storage must also be considered carefully so that there is no direct or indirect contact with food.

7. Supervision of individual health conditions Individual health conditions that manage food must be considered. Personnel who are sick are not allowed to manage food because it can cause contamination.

8. Pest control

Processing and storage of food must avoid all pests that cause contamination ${ }^{11}$.

The safety of ready-to-eat food and drinks also needs to be considered by preventing food pollution. Food safety or food safety is an effort to prevent food and beverages from possible biological, chemical and other objects ${ }^{12}$. Contamination or contamination ${ }^{13}$ what is meant is food and beverage insurance, selection, storage, treatment and sanitation facilities for food. In addition, food traders and processors are required to wear clothing covers, coverlets and headgear to avoid contamination. To maintain public health, food guidance and supervision by local governments must be carried out so that it is safe and suitable for consumption. The supervision efforts on sanitation and food safety hygiene carried out by the Denpasar City Government are adjusted as follows:

a. In 2013 , the Health Office conducted guidance and inspection of household processed food companies with the aim of protecting consumers and checking whether the processed food had met the standards for proper consumption. In addition, inspection of production facilities, hygiene and sanitation, processing methods, materials used, and water quality by means of testing ${ }^{14}$ sesuai dengan tugas dinas kesehatan sebagaimana termuat pada Pasal 38 ayat (2)

\footnotetext{
${ }^{11}$ Ibid.

${ }^{12}$ Islamy, G. P., Sumarmi, S., \& Farapti. (2018). Loc. Cit.

${ }^{13}$ Firmansyah, A. A., \& Evendia, M. (2014). Politik Hukum Penetapan Baku Mutu Lingkungan sebagai Instrumen Pencegahan Pencemaran Lingkungan Hidup. Kanun: Jurnal IImu Hukum, Universitas Syiah Kuala, 16(1), p. 32.

${ }^{14}$ Dinkes. (2013, 20 Mei). Pembinaan dan Pemeriksaan P-IRT. Dinas Kesehatan Kota Denpasar. Retrieved from https://dinkes.denpasarkota.go.id/berita/read/5978
} 
huruf g Peraturan Walikota Denpasar Nomor 33 Tahun 2008 tentang Uraian Tugas Jabatan pada Organisasi Dinas Daerah Kota Denpasar.

b. In 2015 to 2016 , the Denpasar City Government in collaboration with the Indonesian Center for Drug and Food Control (BBPOM) carried out supervision of the circulation of food that is thought to contain dangerous ingredients. Supervision is carried out in various places such as school canteens, street vendors and traditional markets. The Denpasar city government through the relevant agencies and BPPOM testing food using a rapid test kit also provides guidance to traditional market managers to be able to carry out rapid test testing of children independently. The Health Office attaches stickers to every street vendor who has received guidance and supervision so that the community is no longer anxious to consume snacks that street vendors sell. In addition, the mobile lab is also operated so that testing of food and drinks sold in public places is safe for consumption ${ }^{15}$

c. In 2017, the Denpasar City Government in collaboration with BBPOM held a Market Roadshow to review markets that need improvement. In order to monitor market food security, a Market Food Safety Team (TKPP) was formed under the responsibility and supervision of BBPOM Denpasar to avoid the adverse effects of hazardous materials that harm society ${ }^{16}$.

d. In 2018, BBPOM conducted an advocacy to the Denpasar City Health Office to supervise and limit processed food and beverages containing Rodamin B, especially on snacks. ${ }^{17}$.

e. In 2018, the Bali Province Animal Husbandry and Animal Health Service and the UPT. Denpasar City Slaughterhouse provides guidance to the community to prioritize animal hygiene and health and places to slaughter animals so that sacrificial meat is safely consumed in accordance with the duties of the livestock, fisheries and marine services as contained in Article 182 paragraph (1) letters $f$ and $g$ The Mayor of Denpasar Number 33 of 2008 concerning Job Descriptions at the Regional Office of the City of Denpasar. Denpasar City Government has made efforts to foster and supervise the cleanliness of sanitation and food safety very well. Prevention efforts are also made to avoid extraordinary events in the form of food poisoning. The testing of food and beverages is carried out by the Denpasar City Government so that people no longer worry about contamination of processed foods and beverages.

\footnotetext{
${ }^{15}$ Humas. (2016, 10 Mei). Pengawasan Obat dan Makanan. Sekretariat Daerah Kota Denpasar. Retrieved from https://setda.denpasarkota.go.id/berita/read/12264

${ }^{16}$ BPOM. (2017, 21 Februari). Roadshow BBPOM - PemKot untuk Pasar Sehat Denpasar. Badan Pengawas Obat dan Makanan. Retrieved from https://www.pom.go.id/new/view/more/berita/12595/Roadshow-BBPOM--PemKot-untuk-Pasar-Sehat-Denpasar.html

${ }^{17}$ BPOM. (2018, 22 Maret). Berantas Rodamin B: BBPOM Advokasi ke Dinas Kesehatan Kota Denpasar. Badan Pengawas Obat dan Makanan. Retrieved from https://www.pom.go.id/new/view/more/berita/14170/ Berantas-Rodamin-B---BBPOM-Advokasi-Ke-Dinas-Kesehatan-Kota-Denpasar.html
} 


\section{CONCLUSION}

The Denpasar City Government has not implemented the provisions stipulated in Article 19 of the Decree of the Minister of Health No. 942/Menkes/SK/VII/2003 concerning Guidelines for the Requirement of Food Hygiene Sanitation Snacks to regulate the guidance and supervision of food quality in the regions. Although it has not been explicitly regulated, the Denpasar city government has carried out the task of fostering and supervising food quality which is implicitly regulated in the Regional Regulation of Denpasar City Number 7 of 2008 concerning the Organization and Work Procedures of the Regional Office of Denpasar City jo. Denpasar Mayor's Regulation Number 33 of 2008 concerning Job Position Descriptions at the Regional Office of the City of Denpasar. Denpasar City Government through the Health Office; Office of Animal Husbandry, Fisheries and Marine Affairs; and the Office of Industry and Trade carries out the task of fostering and supervising food quality, such as holding Food and Nutrition Alert System (SPKG) activities as a preventive and anticipatory action on nutrition and food problems, carrying out monitoring and quality control of food and non-food animal products and their distribution and guidance to producers in order to improve the quality of goods so as to ensure health, safety and consumer safety. The Denpasar City Government through the health office in collaboration with the Central for Drug and Food Control (BBPOM) supervises and guides street vendors and also routinely checks processed foods and beverages. In addition, the livestock service office also provides guidance to the community to maintain the sanitation and health of sacrificial animals. Producers and business actors must be fostered and supervised so as not to commit fraud in running their businesses such as using food preservatives, not using clean water for sanitation or using food that is not feasible. The community as consumers must also be given counseling and introduction to unhealthy processed foods and beverages so that people are more careful in buying and consuming processed foods and beverages.

\section{REFERENCE}

Ags. (2018, 24 Agustus). Pemkot Denpasar Siagakan 50 Tenaga Kesehatan Hewan. Pemerintah Kota Denpasar. Retrieved from https://www.denpasarkota.go.id/ berita/baca/14026

BPOM. (2017, 21 Februari). Roadshow BBPOM - PemKot untuk Pasar Sehat Denpasar. Badan Pengawas Obat dan Makanan. Retrieved from https://www.pom.go.id/ new/view/more/berita/12595/Roadshow-BBPOM---PemKot-untuk-Pasar-SehatDenpasar.html 
BPOM. (2018, 22 Maret). Berantas Rodamin B: BBPOM Advokasi ke Dinas Kesehatan Kota Denpasar. Badan Pengawas Obat dan Makanan. Retrieved from https:// www.pom.go.id/new/view/more/berita/14170/Berantas-Rodamin-B---BBPOMAdvokasi-Ke-Dinas-Kesehatan-Kota-Denpasar.html

BPOM. (2018, 30 Januari). Berita Keracunan Bulan Juli - September 2017. Sentra Informasi Keracunan Nasional. Retrieved from http://ik.pom.go.id/v2016/beritakeracunan/berita-keracunan-bulab-juli-september-2017

Decree of the Minister of Health of the Republic of Indonesia Number 942/Menkes/SK/ VII/2003 concerning Guidelines for Snack Sanitation Hygiene Requirements.

Dinkes. (2013, 20 Mei). Pembinaan dan Pemeriksaan P-IRT. Dinas Kesehatan Kota Denpasar. Retrieved from https://dinkes.denpasarkota.go.id/berita/read/5978

Firmansyah, Ade Arif, \& Evendia, Malicia. (2014). Politik Hukum Penetapan Baku Mutu Lingkungan sebagai Instrumen Pencegahan Pencemaran Lingkungan Hidup. Kanun: Jurnal IImu Hukum, Universitas Syiah Kuala, 16(1), 19 - 37.

Hasan, K. N. Sofyan. (2014). Kepastian Hukum Sertifikasi dan Labelisasi Halal Produk Pangan. Dinamika Hukum, Universitas Jenderal Soedirman, 14(2), 227 - 238.

Hasanudin, Muhammad. (2012). Puluhan Warga Denpasar Keracunan Nasi Bungkus. Kompas.com. Retrieved from https://nasional.kompas.com/ $\mathrm{read} / 2012 / 07 / 16 / 04384953 /$ puluhan.warga.denpasar.keracunan.nasi.bungkus

Humas. (2016, 10 Mei). Pengawasan Obat dan Makanan. Sekretariat Daerah Kota Denpasar. Retrieved from https://setda.denpasarkota.go.id/berita/read/12264

Islamy, Galang Panji, Sumarmi, Sri, \& Farapti. (2018). Analisis Higiene Sanitasi dan Keamanan Makanan Jajanan di Pasar Besar Kota Malang. Amerta Nutrition, Universitas Airlangga, 2(1), 29 - 36.

Law of the Republic of Indonesia Number 18 of 2012 concerning Food. State Gazette of the Republic of Indonesia, Number 227 of 2012. Supplement to the State Gazette of the Republic of Indonesia, Number 5360.

Mamuaja, Christine F. (2016). Pengawasan Mutu dan Keamanan Pangan. Manado: Unsrat Press.

P., Indra Bagus H. A. (2013). Pelaksanaan Sistem Pengawasan Standar Mutu Pangan Kemasan Kripik Pisang Agung oleh Dinas Perindustrian dan Perdagangan di Kabupaten Lumajang. Kumpulan Jurnal Mahasiswa Fakultas Hukum, Universitas Brawijaya, 1-11. 
Pudjirahaju, Astutik. (2018). Bahan Ajar Gizi: Pengawasan Mutu Pangan. Jakarta: Kementerian Kesehatan Republik Indonesia.

Rahmadhani, Dini, \& Sumarmi, Sri. (2017). Gambaran Penerapan Prinsip Higiene Sanitasi Makanan di PT Aerofood Indonesia, Tangerang, Banten. Amerta Nutrition, Universitas Airlangga, 1(4), 291 - 299.

Regional Regulations of Denpasar City Number 7 of 2008 concerning the Organization and Work Procedures of Denpasar City. Regional Gazette of the City of Denpasar, Number 7 of 2008. Supplement to the Regional Gazette of the City of Denpasar, Number 7.

Regulation of Mayor of Denpasar Number 33 of 2008 concerning the Description of Job Duties in the Denpasar Municipal Service Organization. Regional News of the City of Denpasar, Number 33 of 2008.

Sss. (2014). 22 Warga Denpasar Keracunan Ikan. detikNews. Retrieved from https://news. detik.com/berita/191147/22-warga-denpasar-keracunan-ikan

Surya, I Made. (2014). Bocah Tujuh Tahun Tewas Keracunan. Antara Bali. Retrieved from https://bali.antaranews.com/berita/60031/bocah-tujuh-tahun-tewas-keracunan 